\title{
Opinion
}

\section{How to Make Your New Year's Resolutions Work?}

\section{Soma Mandal, MD*}

Summit Medical Group of New Jersey, Berkeley Heights, NJ 07922, USA

\section{${ }^{*}$ Corresponding author}

Soma Mandal, MD

Internist, Summit Medical Group of New Jersey, Berkeley Heights, NJ 07922, USA; E-mail: somajmandal@gmail.com

\section{Article Information}

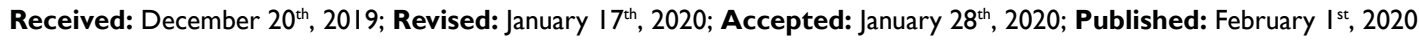

\section{Cite this article}

Mandal S. How to make your new year's resolutions work? Soc Behav Res Pract Open J. 2020; 4(2): 28-29. doi: 10.17/40/SBRPOJ-4-II9

$\mathrm{T}$ There's something about the holidays that make us take stock of where we are. You probably start thinking about those annual resolutions before the New Year arrives.

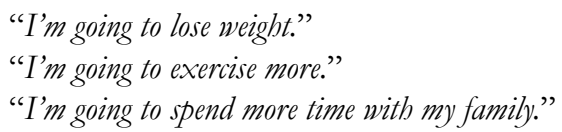

All great goals! And probably ones you make year after year. Sadly, New Year's resolutions are notorious for being left by the wayside rather quickly. About $77 \%$ of people who make New Year's resolutions break them within a few weeks. Even with that statistic, making resolutions is actually a good thing. The key is making them in a way that sets you up for success! You can make your New Year's resolutions before the New Year arrives, or even soon after the first of the year. There is nothing magical about making those decisions or starting on January $1^{\text {st }}$.

\section{You're at Your Most Insightful Around the Holidays}

With the year coming to an end, it's natural to look back at the year. We start to think ahead to the coming year and what we'd like to accomplish. Seeing where you've been and where you want to go gives you clarity. You can envision what it is that you want without the pressure that comes with making a resolution on exactly January $1^{\text {st }}$.

\section{Give Yourself Time to Plan}

There's an old saying, "Failing to plan is planning to fail." Would it surprise you to know that most people abandon their resolutions by mid-January? Why is that? Resolutions are usually broad and lofty ideas. There is not really a plan to achieve them. Sometimes, we don't even really know what the goal is. "I want to lose weight" - what does that mean? What are you going to do to get there? How will you know if you achieved your goal? The number one reason why resolutions fail is that there is no plan. There's just the idea. Motivation wanes quickly and people simply stop.

\section{You Avoid the Pressure of January I ${ }^{\text {st }}$}

Have you ever set a resolution and when January $1^{\text {st }}$ arrives, you have no idea how to get started so you just don't? You're not alone. New Year's resolutions in particular tend to be grand and lofty and lacking in specifics. There is so much pressure to start on January $1^{\text {st }}$ that it can literally stop you before you even start. So, why not pick another date that works for you? Why not before or after the celebrations? There is no right or wrong time to make a change. Having a workable plan can be a huge confidence booster!

\section{You Give Yourself the Chance to Try Again}

You know the saying, "Every day is a chance to start over?" It's so true with goals we set. We are not perfect. Some days we excel. Other days, we miss the mark. It's ok. Our goals are not absolutes. Resolutions can feel like it is "all or nothing", "win or lose", "pass or fail". Why not do something different? Why not give yourself permission to chase your dreams and goals every day? When you give yourself the gift of choosing, you give yourself control of your destiny and not the date on a calendar.

Here are some tips for getting a jump start on those 2020 goals:

- Spend some time reflecting on your year. What did you accomplish? What do you want for 2020?

- Take some time and write down a couple of things you might want to achieve in 2020.

- If you're having trouble narrowing it down, spend some time journaling and exploring what is most important for you.

- Set one or two small, achievable goals to start with

- Identify the small steps you will need to take

- Write your plan down and put it where you'll see it. The act 
of writing your plan down increases your chances of success. (Research backs this up!)

- Set dates to check in with yourself to see how you're doing

- You can start when you are ready

- Commit to making one small change each day that moves you closer to your goal

- You may use January $1^{\text {st }}$ as a check-in date instead of the start date

- Seek out someone to be your support and someone you can be accountable to.

With a little planning, you can step into 2020 strong and moving confidently towards your goals.

\section{FURTHER READING}

1. Chopra M. Living with Intent: My Somewhat Messy Journey to Purpose, Peace, and Joy. New York, USA: Harmony Publisher; 2016.

2. Rubin G. Better Than Before: Mastering the Habits of Our Everyday Lives. London, England: Two Roads Publisher; 2015.

3. Dweck CS. Mindset: The New Psychology of Sucess. Manhattan, USA: Random House Publisher; 2006. 